Neth. J. Agric. Sci., 15 (1967) : 221-228

\title{
Mole activity in relation to pasture management and nitrogen fertilization
}

\author{
G. C. Ennik
}

Institute for Biological and Chemical Research on Field Crops and Herbage (I.B.S.), P.O. Box 14, Wageningen, The Netherlands

Received 26 October, 1966

\section{Summary}

Mole activity, measured by the number of molehills and nests, decreased in the following order of grassland management: cutting, continuous grazing, rotational grazing with low $\mathrm{N}$-application, rotational grazing with high $\mathrm{N}$-application. The irregular distribution of earthworms within each treatment did not allow any conclusions about a relation between the density of worms and mole activity. Data reported in the literature do not support the supposition that treatments with low mole activity may have been unfavourable for worm development. Mole activity was not or only slightly affected by a high soil moisture level.

\section{Introduction}

In a field experiment, in which continuous grazing and rotational grazing were compared, it was observed that mole activity was higher on the continuously grazed plots. The number of molehills was counted in four successive years, the results are presented in this paper.

\section{Method}

Details on the experimental lay-out and the environmental conditions are given in two papers (Ennik, 1957, 1965). The main points will be briefly mentioned here.

The experiment was started in the spring of 1954 on a permanent pasture on sandy soil and comprised the following four treatments in duplicate (Fig. 1).

Treatment 1 and 11 : continuous grazing. Grazed by 2 yearlings per plot from May until October, with a rest period of 5-6 weeks in July-August. Total N-application about $70 \mathrm{~kg} \mathrm{~N}$ per ha per year given as ammonium nitrate limestone in two dressings (spring and summer).

I : no post-grazing treatment;

II: topping of the ungrazed patches and spreading of the dung after each grazing period (in summer and autumn).

Treatment $I I I$ and $I V$ : rotational grazing. Plots alternately grazed by 8-10 yearlings and pregnant heifers about 5-6 times a year, the length of the single grazing periods 


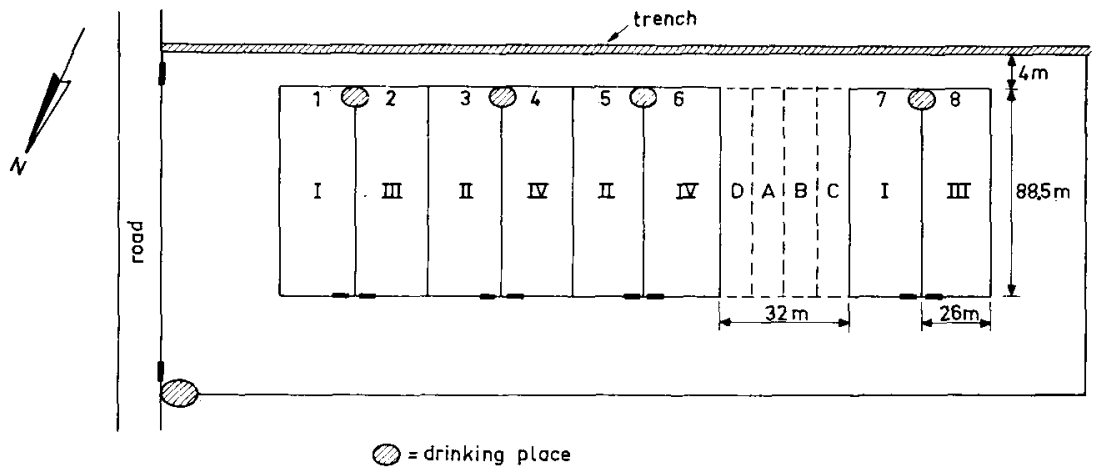

\section{Grazing treatments}

I : Continuous grazing without post-grazing treatment, approx. $70 \mathrm{~kg} \mathrm{~N} / \mathrm{ha}$

II : Continuous grazing with post-grazing treatment, approx. $70 \mathrm{~kg} \mathrm{~N} / \mathrm{ha}$

III : Rotational grazing, low N-application (approx. $70 \mathrm{~kg} / \mathrm{ha}$ )

IV : Rotational grazing, high $\mathrm{N}$-application (approx. $140 \mathrm{~kg} / \mathrm{ha}$ )

Cutting treatments

A : 3-week cutting, approx. $70 \mathrm{~kg} \mathrm{~N} / \mathrm{ha}$

B : 3-week cutting, approx. $140 \mathrm{~kg} \mathrm{~N} / \mathrm{ha}$

C : 5-week cutting, approx. $70 \mathrm{~kg} \mathrm{~N} / \mathrm{ha}$

D : 5-week cutting, approx. $140 \mathrm{~kg} \mathrm{~N} / \mathrm{ha}$

Fig. 1 Lay-out of the experiment. I-IV: grazing treatments; A-D : cutting treatments.

varying from 3-8 days. After each grazing the plots were topped and the dung collected and stored outside the plot for redistribution in winter, except for the first year when the dung was spread after each grazing. $\mathrm{N}$-application was distributed over the season according to the grazing periods.

III: total $\mathrm{N}$-application about $70 \mathrm{~kg} \mathrm{~N}$ per ha per year;

IV: total $\mathrm{N}$-application about $140 \mathrm{~kg} \mathrm{~N}$ per ha per year.

In November 1954, 1955 and 1956, at the end of the grazing season, after a few weeks of rest all plots of the treatments I-IV were alternately grazed once or twice by the whole herd (reduced by selling to about 10 animals) during 1 or 2 days per plot. Thus in the last month of the grazing season stock density was approximately the same for all treatments. In 1957 grazing was already stopped at the end of October.

As indicated in Fig. 1 continuously grazed plots alternated with rotationally grazed ones. The size of the plots was $26 \times 88.5 \mathrm{~m}^{2}$. In 1954 the strip between plots 6 and 7 was cut for hay after grazing in spring. Then one half (strips D and A afterwards) was cut twice in a young stage of growth and the other half (strips $B$ and $C$ afterwards) four times. From 1955 onwards the following cutting treatments were maintained on this area.

A: 3-week cutting. $\mathrm{N}$-application about $70 \mathrm{~kg} \mathrm{~N}$ per ha per year, distributed over the season according to the cuttings.

B: As $\mathrm{A}$ but $\mathrm{N}$-application about $140 \mathrm{~kg} \mathrm{~N}$ per ha per year.

C: 5 -week cutting. N-application about $70 \mathrm{~kg} \mathrm{~N}$ per ha per year.

$\mathrm{D}$ : As $\mathrm{C}$ but $\mathrm{N}$-application about $140 \mathrm{~kg} \mathrm{~N}$ per ha per year. 
The plots were cut by an autoscythe to a height of about $4 \mathrm{~cm}$. After cutting the grass was removed immediately or after a few days' drying. The size of these plots was $8 \times 88.5 \mathrm{~m}^{2}$.

The south side of the field was bounded by a shallow trench at a distance of $4 \mathrm{~m}$ from the experimental plots (Fig. 1), containing water in autumn and winter and during rainy periods in the other seasons. At least during part of the year it served as a drinking place for the moles, which could be concluded from the runs between the experimental plots and the trench. The drinking-troughs within the experimental plots were inaccessible to the moles.

\section{Soil}

The degree of humidity of the soil increased from plot 1 to plot 6 . The rear part of the field (plots 6-8) was rather wet during rainy periods, and in most years suffered from water excess in autumn and winter. Under these conditions the soil was soaked with water. The soil fraction below $16 \mu$ was lowest in the front part of the field $(11 \%)$ and highest in the rear part $(17 \%)$. In December 1954 the organic matter content in the upper $5 \mathrm{~cm}$ layer varied from 7.6 (cutting strip between plots 6 and 7) to 10.7 (plots 5 and 6).

\section{Weather}

In 1954 a dry spring was followed by an extremely wet summer and autumn, resulting in water excess and poaching of the sod. The dry and sunny summer of 1955 was favourable for grass growth on the experimental field. The summer of 1956 was very wet again with excessive water continuing until winter. 1957 was an average season with spells of water excess in the autumn.

\section{Results}

From 1955 to 1958 the numbers of molehills and nests on each plot were counted in February or March. The results are summarized in Table 1.

On 1 February 1955 the molehills were counted after the snow-cover had melted. Especially the rear part of the field was very wet. This did not seem to affect the number of molehills, however. The highest number of hills was found on the continuously grazed plots, whereas (apart from the cut plots) the nests occurred on these plots only. No effect of the post-grazing treatment was observed. As to the rotationally grazed plots the number of molehills was much smaller on the plots with high nitrogen application. The average hill number on the cutting strip was about the same as on the rotationally grazed plots with low nitrogen application. Though the number was higher under more frequent cutting, it is doubtful whether this is reliable in view of the results in the next years. In contrast with the rotationally grazed plots a few nests were present on the cutting strip.

In the beginning of February 1955 the moles were controlled by inserting poisoned meat into their nests, after which the hills were levelled. After a week poison was inserted into several new gangways and all hills were levelled again. On 28 February, 


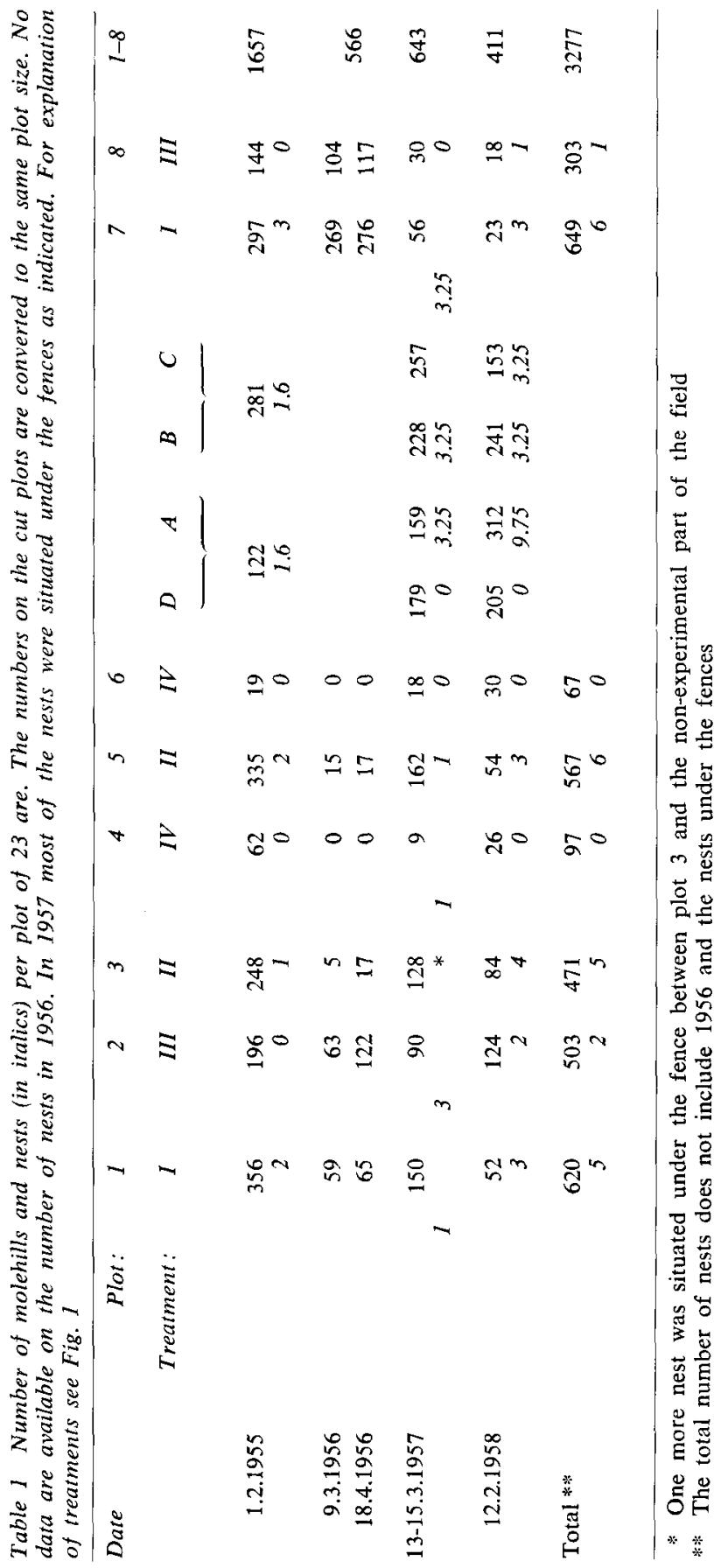


during a frost period, the hill numbers on the plots 1-8 were counted and amounted to $147,45,100,56,54,49,10$ and 15 , respectively. These data were not included in Table 1 , because the intensity of control may not have been quite the same for all plots. The data indicate, however, that at that moment mole activity was greatest in the front part, i.e. the drier part of the experimental field.

Control of the moles with poison and levelling of the hills was continued in March. From August until December control was restricted to setting some traps in which over 30 moles were caught. On 9 March 1956 after a period of heavy frost the number of molehills was counted which was repeated on 18 April (Table 1). Except for the plots 7 and 8 the number was low compared to 1955. The number was highest on the continuously grazed plots without post-grazing treatment and lowest on the rotationally grazed plots with high $\mathrm{N}$-application. The continuously grazed plots with post-grazing treatment were conspicuous this time by their relatively low number of hills. On 21 April 1956 all hills were levelled after which hardly any new hills were thrown up. At the end of this month poison was inserted into some gangways between the experimental field and the trench at the southside. Without further control of the moles the hills were levelled again at the beginning of January 1957. On 13/15 March the number of hills and nests was counted (Table 1). The highest number of both hills and nests was found on the cut plots. Within this group the hill number per plot varied considerably, but the differences did not appear to be related to the frequency of cutting or the amount of nitrogen applied. Concerning the grazed plots the highest number of hills was found again on the continuously grazed plots, no matter whether post-grazing treatment was applied or not, and by far the lowest number was found on the rotationally grazed plots with high nitrogen application. With grazing the nests were only found on the continuously grazed plots or under the wire fences between the plots. In contrast with the preceding year the hill-number on the rear part of the experimental field was relatively low. After counting all molehills were levelled. From March to May 17 moles were killed by traps. The molehills and nests were counted for the last time on 12 February 1958. Again the highest number was present on the cut plots. In relation to the results in the preceding years the differences in number between the plots within this group are too irregular for any further conclusions. Concerning the grazed plots the lowest number of molehills and nests was once more found on the rotationally grazed plots with high nitrogen application. This time the number of hills was so high on one of the rotationally grazed plots with low N-application (plot 2) that the average hill-number for this treatment was higher than under the conditions of continuous grazing, but this did not hold for the number of nests. Like in 1957 , the number of hills was relatively low on the rear part of the experimental field.

\section{Discussion}

Surveying the data of all years (for the grazing treatments summarized in Table 2) it is found that the frequency of molehills and nests was highest on the cut plots, followed by the continuously grazed plots and the rotationally grazed plots with low nitrogen application, respectively. By far the lowest frequencies were found on the rotationally grazed plots with high nitrogen application. Apart from a few irregularities this order occurred in each of the observation years. Within the group of cutting treatments and also within the group of continuous grazing (i.e. with and without post- 
grazing treatment) the distribution of hills was irregular from year to year, so that no conclusions may be drawn about a preference of moles for the treatments within these groups.

Because the experimental set-up was not designed to observe mole activity, only a restricted statistical analysis of these data is possible. Though successive counts were only made at one year intervals and control of the moles occurred in between, the hill numbers on the same plots in consecutive years may be more or less dependent on each other. On this assumption application of the multiple range test on the hill numbers of the grazed plots indicates that the difference in hill number between continuous grazing (with and without post-grazing treatment) and rotational grazing with high $\mathrm{N}$-application is significant at the $5 \%$-level. If the hill numbers in consecutive years should be quite independent of each other the difference between continuous grazing and rotational grazing with high $\mathrm{N}$-application is significant at the $1 \%$-level and the difference between rotational grazing with low $\mathrm{N}$-application and rotational grazing with high $\mathrm{N}$-application at the $5 \%$-level. The difference between continuous grazing and rotational grazing with low $\mathrm{N}$-application is not significant. The number of nests, however, was not considered in this test.

During the observations attention was paid to the depth of the gangways under the different treatments. There were no indications that the differences in hill-number were caused by a difference in behaviour of the moles. The hill-number may therefore be considered a measure for the activity of the moles under the different conditions. Because moles prefer quiet environmental conditions, the trembling of soil caused by

Table 2 Average number of molehills per plot in 19551958 and total number of nests in 1954, 1957 and 1958 on the grazing treatments. For explanation of treatments see Fig. 1

\begin{tabular}{lrrrr}
\hline \multicolumn{1}{c}{ Treatment: } & $I$ & $I I$ & $I I I$ & $I V$ \\
Average hill number & 159 & 130 & 101 & 21 \\
Total nest number & 11 & 11 & 3 & 0 \\
\hline
\end{tabular}

Table 3 Minimum, maximum and average number and dry weight $(\mathrm{g})$ of worms per $m^{2}$ in 4 patches per plot on 8 November 1957. For explanation of treatments see Fig. 1

\begin{tabular}{|c|c|c|c|c|c|c|c|c|c|c|c|c|}
\hline Plot: & 1 & 2 & 3 & 4 & 5 & 6 & & & & & 7 & 8 \\
\hline Treatment: & $I$ & $I I I$ & $I I$ & $I V$ & $I I$ & IV & $D$ & $A$ & $B$ & $C$ & $I$ & $I I I$ \\
\hline \multicolumn{13}{|l|}{ Number } \\
\hline Minimum & 40 & 70 & 43 & 24 & 13 & 20 & 30 & 10 & 47 & 44 & 21 & 14 \\
\hline Maximum & 111 & 101 & 88 & 315 & 142 & 29 & 42 & 72 & 95 & 61 & 117 & 54 \\
\hline Average & 77 & 84 & 65 & 131 & 64 & 25 & 36 & 41 & 75 & 51 & 84 & 30 \\
\hline \multicolumn{13}{|l|}{ Weight } \\
\hline Minimum & 8.5 & 24.5 & 16.5 & 8 & 5 & 6 & 11.5 & 3 & 18 & 19 & 4.5 & 2.0 \\
\hline Maximum & 35 & 46.5 & 46 & 80 & 50.5 & 10.5 & 15 & 27.5 & 37.5 & 21 & 55 & 18.5 \\
\hline Average & 24 & 36 & 26.5 & 34.5 & 25.5 & 7.5 & 13 & 16 & 27.5 & 20 & 33.5 & 8 \\
\hline
\end{tabular}


moving stock might affect the frequency of occurrence of the moles. Though this may perhaps explain their preference for the cut plots, it does not hold for the differences in frequency between the grazed plots, as will be shown for the winter of 1954-1955. In the autumn of 1954 the cattle were taken from the experimental plots from 5 October until 2 November, in which period the droppings were spread. In November the plots 1-8 were alternately grazed once or twice by the whole herd, the total of grazing-days for the different plots being approximately $4,4,2,2,1,3$, 1 and 3 days, respectively. On 1 December the number of droppings per plot were counted, amounting to $261,349,148,159,68,265,105$ and 254 respectively. They also indicate the grazing intensity per plot since 5 October 1954. A comparison with the data in Table 1 shows that there is no relation between the grazing intensity during the last few months before counting the molehills and the frequency of molehills. Apparently the activity of moles is determined by other factors, of which the amount of food and its accessibility may be most important. To check this, earthworm-population counts were made on 8 November 1957. For this purpose 4 areas of $1 \mathrm{~m}^{2}$ per plot were soaked with a solution of potassium permanganate. The worms expelled were identified (mainly Allolobophora caliginosa and Lumbricus rubellus and a few A. chlorotica), counted, dried and weighed. The variation in worm number (Table 3) and weight between the 4 areas of one plot was much wider than the variation between the different plots. Statistical analysis did not therefore show any significant difference between the treatments and no conclusions could be drawn about a relation between the density of the worm population and mole activity. Due to the treading by the cattle the soil on the grazed plots may be firmer and more difficult to burrow than that on the cut plots. Thus the accessibility of the food may be better on the cut plots, which might explain the preference of the moles for the latter.

Literature about the relation between pasture management and mole activity is scarce. According to Bool and Garritsen (1953) the mole has a preference for those pastures which are well managed and fertilized (especially with manure) because they contain more earthworms than pastures in a poor condition. Though the qualifications 'well managed' and 'poor condition' are not further defined, they probably refer to more diverging conditions than our rotational and continuous grazing.

It is stated by Doeksen (1953) that over $95 \%$ of the mole's food consists of earthworms. Thus it may be expected that mole activity is related to the density of earthworms. Edmond (1963) found a remarkable reduction in the worm population (consisting of $A$. caliginosa and $L$. rubellus) by treading especially on wet soil. This may have been an unfavourable factor for the worm population in the grazed plots. On the other hand the worm population of these plots may have been stimulated by the return of dung and urine (Sears and Evans, 1953). Because it is not known which factor dominates in our case, there is no saying whether the worm population should be expected highest on the cut plots or on the grazed ones.

Heath (1962) compared the effect of frequent rotational grazing and frequent cutting without nitrogen added and with $314 \mathrm{~kg} \mathrm{~N}$ per ha per year on the earthworm population of grass/clover leys. On an average he found a higher density of worms with grazing than with cutting, and with $314 \mathrm{~kg} \mathrm{~N}$ per ha than without nitrogen added, though the differences were not statistically significant. In Heath's investigation, however, the species $A$. caliginosa and $L$. rubellus represented only a small part of the worm population. Sears and Evans (1953) reported higher worm populations (A. caliginosa and $L$. rubellus) on higher yielding pastures and Watkin (1954) found that heavy applications of nitro-chalk to sheep-grazed pasture increased earthworm popu- 
lations indirectly by stimulating the grass production and hence increasing the amount of dung returned to the soil. These results seem contradictory to those of our experiment in which mole activity was higher under grazing conditions with low $\mathrm{N}$-application rather than high $\mathrm{N}$.

It is shown in Table 1 that the number of molehills fluctuated considerably from year to year, but this could have been affected by the more or less intensive control in the different years. In the spring of 1955, following the extremely wet summer and autumn of 1954, a relatively high number was found on all plots. In spite of the markedly wetter conditions on the rear part of the field, causing considerable differences in the botanical composition (Ennik, 1965), the density of molehills on this part of the field was as high as on the front pari, indicating that moles are not susceptible to wet conditions. This was also stated by Graf (1958). In the spring of 1956, after the relatively dry summer of 1955 , a low number of molehills was found on the front (= drier) part of the field, though moisture supply on these plots was still adequate for normal grass growth. In 1957 and 1958, following the very wet season of 1956 and the rather wet autumn of 1957, respectively, the hill number tended to be lower on the rear part of the field (plots 6-8), which could be related to the higher soil-moisture level.

\section{References}

Bool, C. H. en Garritsen, J. G., 1953. De bestrijding van mollen. Landbouwvoorlichting, $10: 462-466$. Doeksen, J., 1953. De mol. Landbouwvoorlichting, 10:459-461.

Edmond, D. B., 1963. Effects of treading perennial ryegrass (Lolium perenne L.) and white clover (Trifolium repens L.) pastures in winter and summer at two soil moisture levels. New Zealand J. Agr. Res., $6:$ : 265-276.

Ennik, G. C., 1957. Een vergelijking van de invloed van standweiden en omweiden op de botanische samenstelling van grasland (A comparison of the influence of continuous grazing and rotational grazing on the botanical composition of grassland). Jaarb. I.B.S., Wageningen, pp. 27-37.

Ennik, G. C., 1965. The influence of management and nitrogen application on the botanical composition of grassland. Neth. J. Agr. Sci., 13:222-237.

Graf, A., 1958. Massnahmen zur Verhütung von Mäuseschäden im Feldbau. Mitt. Schweiz. Landw., 6: 49-60.

Heath, G. W., 1962. The influence of ley management on earthworm populations. J. Brit. Grassland Soc., $17: 237-244$.

Sears, P. D. and Evans, L. T., 1953. Pasture growth and soil fertility. III. The influence of red and white clovers, superphosphate, lime, and dung and urine on soil composition, and on earthworm and grassgrub populations. New Zealand J. Sci. Technol., 35 Sect. A, Suppl. 1: $42-52$.

Watkin, B. R., 1954. The animal factor and levels of nitrogen. J. Brit. Grassland Soc., $9: 35-46$. 